\title{
INFLUENCES OF PHILANTROPHIC ACTIVITIES RUMAH BELAJAR CERIA (RBC) TOWARD THE WELFARE OF SOCIETY IN SUNGAI PEDADO
}

\author{
Siti Mardiah,1 Rambo Saputra2 \\ Universitas Islam Negeri Raden Fatah Palembang \\ Email:1sitimardiyah_uin@radenfatah.ac.id,2saputrarambo96@yahoo.com
}

\begin{abstract}
By utilizing waqf land located in Sungai Pedado village, the Rumah Belajar Ceria community conducts various social activities. The initial goal of this community was to help increase of the level of education in this area. Then the activity continues on the aspect of economic empowerment of the community by conducting Mushroom cultivation. This study aims to describe the activities of the RBC community in improving the social welfare of the Sungai Pedado village community. The research methodology uses a mix of used method with descriptive analysis and the data analysis with the CIBEST models to measure the level of effectiveness of activities on community economic empowerment in the Macmur program. The results showed that the existence of the RBC mushroom livestock program could improve people's welfare and reduce the index of material poverty. The household classification is based on the CIBEST Model roomates is categorized as prosperous (quadrant I) as many as 28 Households, material poor (quadrant II) as many as 2 poor, spiritual Households are absent, and reviews those that fall into absolute poor category are none.
\end{abstract}

Key words: Rumah Belajar Ceria, Welfare, Philantophy

\section{INTRODUCTION}

Philanthropy gets closer attention when Civil Society concept is shown up, this concept explains the need for the Civil Society of independence is in accordance with its role of limiting authoritarian government, increase community empowerment, reducing the negative impact of market forces and demand public accountability and to improve the quality and the inclusive nature of governance there.1

In the last 5 years, the role and involvement of youth in philanthropy increased significantly. Among the activities undertaken to establish a foundation or communitybased organizations to develop a range of social programs that interest or concern, volunteer and donor in various social organizations that exist. Youth involvement in philanthropy has changed the map and pattern of philanthropy in Indonesia.

According Timotheus Lesmana Widjaja, the Association of Indonesian Philanthropy. Widjaja said that Philanthropy is no longer synonymous with generosity activity "parent" or "rich people" who usually do in the old days or retirement. Philanthropy is also no longer synonymous with charity activities in the form of

1 Chusnan Jusuf "Modern Philanthropy Social go towards reconstructing" Journal of Research and Development of Social Welfare, Vol 12, No. 01, 2007: 74-80

Website: http://jurnal.radenfatah..ac.id/index.php/ieconomics 
donations to religious activities, disaster management, sponsorship and social services. Humanitarian and social philanthropic activities empowerment of young people do together in a community to take advantage of information technology and culture. The issue of concern is how to package the philanthropic program to make it more popular, fun and contains aspects of economic empowerment.2

According to Erna Witoelar, Indonesian Philanthropy Chair of the Steering Board, the contribution of young people in developing philanthropy has indirectly contributed to change the pattern of which is identical and focused on funds. Philanthropy is not only seen as a social activity, but as a social investment and sustainable high impact. They also sees its involvement in philanthropy as an investment for the development of character and capacity to become a leader in the future. 3

Initiative philanthropy is generally initiated by an individual or a particular community and promoted through the use of social media (FB, twitter, instagram, etc) which then responded and supported by the public. They move with a variety of programs, ranging from sponsorship, social services, disaster management, education, health, environment preservation to economic empowerment. In contrast to social organizations or NGOs, community organizations, mostly non-legal, governance structure is fluid, interactive and encourage the involvement of communities, particularly young people in its activities.

Palembang is home to many philanthropic community themes of poverty on the basis of its activities. One community that runs the philanthropic activity is Rumah Belajar Ceria. Beginning with displaced utilizing waqf land in the village of Sungai Pedado. Social activity early this community concentrated on teaching and learning, and social activities carried out by the empowerment and economic development of society and the development of local tourism.

Sungai Pedado Village located in Kertapati recorded a total number of poverty with 29.723 families.4 This condition is worsened by the geographic location is in the coastal rivers of musi make a village water became brackish, geographical location is not too far from the city center is not a guarantee to get education facilities standardized, and therefore quality education in this area is very low. Rumah Belajar Ceria is a youth community-based and engaged in Sungai Pedado that in the village.

In addition to performing education, since 2016 the community began to implement programs of economic empowerment in the form of cattle fungus with the name "Maniac Jamur". Until the authors conducted a study on February 14, 2019, the number of people who nurtured are 30 people with the distribution of 15 of the womans as a manager of mushrooms and 15 people from the mans as farmers.

This study aimed to describe the effectiveness and impact of training programs conducted by the RBC community to community beneficiaries of the program by performing analysis approach Center of Islamic Business Economic Studies (CIBEST), with this analysis technique, researchers will get two welfare measures in terms of material and spiritual. In this study, authors conducted a study entitled An Influences

2 Timotheus Lesmana Widjaja, Seminar Philanthropy Goes To Campus Learning Forum, October 17th, 2018, University of Indonesia.

3 Erna Witoelar, The Millennial Generation Change Map Philanthropy Indonesia, https://filantropi.or.id, Accessed March 17, 2019, at 06:27.

4 https://bpssumsel.go.id, Accessed February 14, 2019

Website: http://jurnal.radenfatah..ac.id/index.php/ieconomics 
Of Philantrophic Activities Rumah Belajar Ceria (RBC) Toward The Welfare Of Society In Sungai Pedado Village, District Kertapati.

Implementation of this study is to provide insight and education on the activities of philanthropic youth, help develop insights and references of knowledge about philanthropy youth, provide information for the AQAQ government as a reference in the development of program-based society, and being a role model for the role of young people in helping to improve the welfare of the community.

\section{LITERATURE REVIEW}

Discussion on Philanthropy conducted by Jusuf Chusnan 5Imron Hadi Tamin,6 This study seeks to describe how the contribution of Islamic philanthropy in improving the welfare of villagers Sukereno Jember. In this study failed to find that philanthropy is done by citrus growers to poor families either in the form of charity and empowerment as well as the provision of production resources has contributed to increased prosperity. There is also a study was also conducted on Philanthropy conducted by Amaroh7, Amaroh discuss the potential and constraints faced by Philanthropy Islam, Islam sat philanthropy as a form of good deeds that have broad impact for the creation of justice, prosperity, and freedom. In the macroeconomic context, the accumulated social potential of communities can balance the demand side. This potential at a certain point can lower the average propensity to consume the poor.

Research on the impact of community business development program on poverty reduction was made by Beik (2009) with case studies Republika Dhuafa Wallet. Results from these studies showed that after the distribution of zakat funds poverty will be reduced by 10 per cent from 84 per cent to be 74 per cent. Beik and Arsyianti (2015) established the model CIBEST and do research with title Construction of CIBEST Model as the Measurement of Poverty and Welfare Indices From Islamic Perspective. The results suggest that the concept of poverty and wealth in Islamic perspective is not only seen from the dimensions of the material, but also from the spiritual dimension. This study formulated a model of CIBEST consisting of well-being index, the index of material poverty, spiritual poverty index, and the absolute poverty index. This index is based on the concept of CIBEST quadrants representing the Islamic concept of poverty and welfare. 8

In 2015, Primary analyze the impact productive utilization of zakat to reduce poverty with a case study Masyarakat Mandiri PT Dhuafa Wallet. The research results showed that the average household income has increased after their mustahik distribution of zakat funds. Qonita (2015) conducted a study in BAZIS Jakarta which

\footnotetext{
5 Chusnan Jusuf "Modern Philanthropy for Social Development" Journal of Research and Development of Social Welfare, Vol 12, No. 01, 2007: 74-80

6Imron Hadi Tamin, "Peran Pilanthropy In Poverty In The Community Lokal", Journal of Sociology of Islam, Vol. 1, 1. (Udayana University, 2011) (2014)

7Amaroh S, "Filantropi Islam di Indonesia: Potensi dan Kendala", Addin Journal, vol. 2, issue 1,

8Irfan Syauqi Beik, Laily Dwi Arsyianti, "Construction Of Cibest Model As Measurement Of Poverty And Welfare Indices From Islamic Perspective”, Journal of Al-Iqtishad Vol 7, No. 01. UIN Syarif Hidayatullah Jakarta, 2015)
}

Website: http://jurnal.radenfatah..ac.id/index.php/ieconomics 
shows that the distribution of zakat funds yangdilakukan by Jakarta Provincial BAZIS proven to reduce poverty and inequality mustahik.9

Widyaningsih (2016) conducted a study on the impact of zakat in South Sulawesi by using the model CIBEST and showed similar results. Muslihah (2016) also analyze the impact of the distribution of zakat funds committed by LAZ PM Al Bunyan in reducing poverty results from this study is the distribution of zakat funds can improve household welfare mustahik able to reduce poverty.10

\section{THEORETICAL FRAMEWORK}

According to Chambers, poverty is understood as a state of lack of money and goods to ensure survival. In broad terms, saying that poverty is an intergrated concept that has five dimensions, namely: poverty (proper), powerlessness (powerless), the vulnerability of emergency (state of emergency), dependence (dependence), and alienation (isolation), both geographically and sociologically.11 Poverty is classified into five types 12, Namely absolute poverty, relative poverty, structural poverty, kemiskunan situational or natural and cultural poverty.

In Islam, poverty and inequality is seen as sunatullah and can not be eliminated. Islam never talked how to eliminate poverty, but Islam talk about how to minimize poverty and achieve prosperity. One of the instruments that can minimize poverty is to tithe. 13

In Islam, poverty has a multidimensional nature. The point is that poverty is not only seen from the material aspect alone but also see the spiritual aspect. Thus the concept of poverty is based on the proposition of the Qur'an as contained in paragraph Thoha Letter 118-120 and Surah Al Quraishi verses 3-4 that states that the basic needs that must be met by Muslims are able to practice their religion properly, tercukupinya needs clothing, food, and shelter, as well as the absence of fear or lack of threat and pressure from various sides 14

\section{RESEARCH METHODS}

Good research is research in accordance with the procedure, have a clear objective, carried out systematically and is a reflection of the desirability of promoting the knowledge of something, as well as answering questions or solve problems in

9 Primary C.." Productive utilization of Zakat in Reducing Poverty beradasarkan CIBEST Model: A Case Study of PT for Community LAZ PM Al Bunyan”, Thesis. Bogor (ID): Institut Pertanian Bogor. (2015)

10 Nety Widyaningsih. "Impact Study Zakat in South Sulawesi with Model CIBEST". AlIqtishodia. JURNAL EKONOMI ISLAM REPUBLIKA , KAMIS,28 JANUARI 2016

11Adit Agus Prasetyo. "Analysis of the factors affecting the level of Poverty (case study 35 districts / municipalities in Central Java Year 2003-2007)". Thesis. (Faculty of Economics, University of Diponegoro, Semarang, 2010)

12John Mardimin, Critique Dimension Development Process in Indonesia. (Jogjakarta: Canisius, 1996),

13Didien Hafidhuddin, et al. The Power of Zakat Zakat Management Comparative Studies of Southeast Asia. (Malang State Islamic University in cooperation with the Research Center of Zakat and Waqf "El-Zawa" 2008).

14Irfan Syauqi Beik, Laily Dwi Arsyianti, "Construction Of Cibest Model As Measurement Of Poverty And Welfare Indices From Islamic Perspective” Journal of Al-Iqtishad Vol 7, No. 01. (UIN Syarif Hidayatullah Jakarta, 2015)

Website: http://jurnal.radenfatah..ac.id/index.php/ieconomics 
everyday life.15 Scientifics an inscription realized if the proposed subject matter is concluded through a systematic procedur using proofs are quite convincing form of evidence obtained objectively.16 Therefore the use of appropriate methodology is very important in a study. Through research methods will produce the optimal work and inferences can be generalized or accountable. 17

This type of research is a field research (field reseach) which is descriptive explorative. This research study design using a mixture (mixed methodology). According Sugiyono (2011), research methods combined (mixed methods) is a research method that combines or combine quantitative methods with qualitative methods to be used together in a research activity, in order to obtain more comprehensive data, valid, realible and objective.

Field research can also be referred to as empirical research, the research data and information derived from activities in the field of research work. 18 This type of research because researchers have been collecting data from the field which further correlated with the theory used in the research.

Description is the exposure to the words clearly and in detail or in other words the decomposition of words in detail. While the interpretation is the process of interpretation.19 With this, the researchers explained in a clear and detailed results of the study are then interpreted based on the theoretical basis that is used.

Sumber of data in the study were classified into two types, namely:

1. Primary data: the form of the results of questionnaires and interviews with respondents receiver coaching program totaling 30 peoplezo in Sungai Pedado, and community administrators RBC.

2. Secondary data, secondary data is data derived from a second source that can be obtained through books, brochures and articles were obtained from the website associated with this research.

The population in this study is the recipient of the mushroom farm economic empowerment program totaling 30 people in the village of River Pedado, therefore all of this population can be reached by the researchers then all the population used as a sample. The sampling technique is called the saturated sampling. Saturated Sampling is sampling technique when all members of the population used as a sample. This is often done when the population size is relatively small, less than 30 people. Another term saturated sample census, where all members of the population sampled.21

Data collection techniques in studies using several techniques were questionnaires, observations, and interviews.Data analysis technique used in this study is divided into two, using techniques Qualitative analysis and quantitative analysis techniques. Qualitative analysis techniques used in this research is descriptive analysis. Descriptive

15Nur Indriantono and Bambang Supomo, Business Research Methodology: To Accounting and Management, Cet. 1 (Yogyakarta: BPFE, 2002), p 3.

25

16Mubyarto and Sueratno, Economic Research Methods, Cet. I (Yogyakarta: FE UGM, 1996), p 2005), p 10

17Supardi, Economics and Business Research Methodology, Cet. I (Yogyakarta, UII Press,

18 Ibid. p 34

Publisher, $\mathrm{p} 250$

${ }_{19}$ Em Zul Fajri and Queen Aprilia Twilight, Complete Dictionary of Indonesian, undated, Difa

${ }^{20}$ Results of interviews with the management of RBC, February 13, 2019 17:40 AM.

${ }_{21}$ Sugiyono. Business Research Methods. (Alfabeta, Bandung. 2001), p.61

Website: http://jurnal.radenfatah..ac.id/index.php/ieconomics 
analysis is used to describe how the roles and activities of the House Read Cheers philanthropic activities in the village Pedoda river. While quantitative data analysis techniques to the questionnaire that has been deployed to see one of the philanthropic activities in the economic empowerment program.

Calculations used as a basis of calculation in this study is the value of Material Value (MV) or household poverty and household income per month. Material Value (MV) is used to measure the minimum standards of material that must be met by households. MV value obtained by multiplying the price of goods and services consumed (Pi) with a minimal amount of goods and services required (Mi). Mathematically, the MV can be formulated as follows:

$$
M V=\sum_{i=1}^{n} P i M i
$$

Information:

MV = The minimum standard of material that must be met by households (US \$ or other currency) or could be called poverty line Material

$\mathrm{Pi} \quad=$ The price of goods and services (US \$ or other currency)

$\mathrm{n} \quad=$ The minimum amount of goods and services required

Because of their limitations and do not do the survey in this study, the value of MV used in this study is the value of the existing MV namely Palembang material poverty line will be converted into the household poverty line per capita per month. According to the poverty line of Palembang city in 2018 amounting to $\mathrm{Rp} 397.150$ (BPS South Sumatera, 2018). Into a study area with a population of 8,266,983 and the number of households 1,813,578 (BPS South Sumatera, 2018), then:

$$
\text { The average household size: } \overline{\frac{8.266 .983}{1.813 .578}=4,558}
$$

So the household poverty line (MV) obtained are:

$$
\begin{aligned}
\text { MV } & =397150 \times 4.558 \\
& =1,246,926 \text { per household per month }
\end{aligned}
$$

Spiritual poverty line or Spiritual Value (SV) is obtained beradasarkan indicator spiritual needs and the fulfillment of the five variables that determine the score of the spiritual. Five variables are prayers, alms, fasting, household environment, and government policies. To assess the scores of the variables used a Likert scale of 1-5 as shown in Table 1

Tabel.1

Spiritual score CIBEST

\begin{tabular}{|l|l|l|l|l|l|l|}
\hline \multirow{2}{*}{$\begin{array}{l}\text { variab } \\
\mathrm{e}\end{array}$} & \multicolumn{4}{|l|}{ scale Llikert } & standard \\
\cline { 2 - 6 } & 1 & 2 & 3 & 4 & 5 & Poverty \\
\hline Salat & $\begin{array}{l}\text { Prohibit others } \\
\text { pray }\end{array}$ & $\begin{array}{l}\text { Rejecting } \\
\text { the } \\
\text { concept of }\end{array}$ & $\begin{array}{l}\text { Shall not be } \\
\text { routinely } \\
\text { praying }\end{array}$ & $\begin{array}{l}\text { Routine } \\
\text { obligatory } \\
\text { prayers, but }\end{array}$ & $\begin{array}{l}\text { Routine } \\
\text { obligatory } \\
\text { prayers in }\end{array}$ & $\begin{array}{l}\text { The average } \\
\text { score for the } \\
\text { families who }\end{array}$ \\
\hline
\end{tabular}

Website: http://jurnal.radenfatah..ac.id/index.php/ieconomics 


\begin{tabular}{|c|c|c|c|c|c|c|}
\hline & & prayer & & $\begin{array}{l}\text { not always in } \\
\text { congregation }\end{array}$ & \begin{tabular}{l}
\multicolumn{2}{l}{ congregation } \\
and praying \\
sunnah
\end{tabular} & \multirow[t]{5}{*}{$\begin{array}{l}\text { are spiritually } \\
\text { poor is } 3(\mathrm{SV} \\
=3)\end{array}$} \\
\hline $\begin{array}{l}\text { Fastin } \\
\mathrm{g}\end{array}$ & $\begin{array}{l}\text { Prohibit people } \\
\text { fast }\end{array}$ & $\begin{array}{l}\text { Rejecting } \\
\text { the } \\
\text { concept of } \\
\text { fasting }\end{array}$ & $\begin{array}{l}\text { Obligatory } \\
\text { fasting is not } \\
\text { full }\end{array}$ & $\begin{array}{l}\text { Only fasting } \\
\text { compulsory in } \\
\text { full }\end{array}$ & $\begin{array}{l}\text { Fasting } \\
\text { obligatory and } \\
\text { sunnah fasting }\end{array}$ & \\
\hline $\begin{array}{l}\text { Zakat } \\
\text { and } \\
\text { Infaq }\end{array}$ & $\begin{array}{l}\text { Prohibit others } \\
\text { to tithe and } \\
\text { infaq }\end{array}$ & $\begin{array}{l}\text { Refuse } \\
\text { alms and } \\
\text { infaq }\end{array}$ & $\begin{array}{l}\text { Never } \\
\text { berinfaq } \\
\text { even once a } \\
\text { year }\end{array}$ & $\begin{array}{lr}\text { Pay } & \text { zakat } \\
\text { fitrah } & \text { and } \\
\text { zakat } & \end{array}$ & $\begin{array}{l}\text { Pay zakat fitrah, } \\
\text { zakat and alms } \\
\text { infaq }\end{array}$ & \\
\hline $\begin{array}{l}\text { Family } \\
\text { enviro } \\
\text { nment }\end{array}$ & $\begin{array}{l}\text { Prohibit family } \\
\text { members } \\
\text { worship }\end{array}$ & $\begin{array}{l}\text { To refuse } \\
\text { enforceme } \\
\text { nt of } \\
\text { worship }\end{array}$ & $\begin{array}{l}\text { Worship } \\
\text { considers } \\
\text { matters of } \\
\text { family } \\
\text { members }\end{array}$ & $\begin{array}{l}\text { Worship } \\
\text { support } \\
\text { family } \\
\text { members }\end{array}$ & $\begin{array}{ll}\text { Building } & \text { a } \\
\text { supportive } & \\
\text { family } & \\
\text { atmosphere } & \text { of } \\
\text { worship } & \\
\text { together } & \\
\end{array}$ & \\
\hline $\begin{array}{l}\text { Gover } \\
\text { nment } \\
\text { policy }\end{array}$ & $\begin{array}{ll}\text { Prohibits } & \text { the } \\
\text { practice } & \text { for } \\
\text { family } & \\
\text { members } & \end{array}$ & $\begin{array}{l}\text { To refuse } \\
\text { enforceme } \\
\text { nt of } \\
\text { worship }\end{array}$ & $\begin{array}{l}\text { Considers } \\
\text { private } \\
\text { matter } \\
\text { public } \\
\text { worship }\end{array}$ & $\begin{array}{l}\text { supports } \\
\text { worship }\end{array}$ & $\begin{array}{ll}\text { Creating an } \\
\text { environment } \\
\text { conducive } \\
\text { worship }\end{array}$ & \\
\hline
\end{tabular}

Source: Irfan Syauqi Beik, Laily Dwi Arsyianti (2016: 93)

Based on Table 1, the obtained value SV is 3. This means that if a household has a score of less than or equal to 3 then it should be categorized as poor spiritually. SV value is derived as follows:

$$
\begin{aligned}
& H i=\frac{V p}{5}+\frac{V f}{5}+\frac{V z}{5}+\frac{V h}{5}+\frac{V g}{5} \\
& \text { Information } \\
& \mathrm{Hi} \quad: \text { Actual Score household members to-i } \\
& \mathrm{Vp} \quad: \text { Scores of prayer } \\
& \mathrm{Vt} \quad: \text { Scores of fasting } \\
& \mathrm{VZ} \quad: \text { Score zakat and infaq } \\
& \mathrm{Vh} \quad: \text { Score working environment } \\
& \mathrm{Vg} \quad: \text { Scores of government policy }
\end{aligned}
$$

After calculating SV and MV then households can be categorized into quadrants CIBEST as follows:

Table. 2

\section{Category Household}

\begin{tabular}{|l|l|l|}
\hline Actual score & $\leq$ Value MV & $>$ Value MV \\
\hline$>$ SV Value & $\begin{array}{l}\text { Rich spiritual, material } \\
\text { Poor (Quadrant II) }\end{array}$ & $\begin{array}{l}\text { Spiritually rich, rich } \\
\text { materials (Quadrant I) }\end{array}$ \\
\hline$\leq$ SV Value & $\begin{array}{l}\text { Spiritually poor, poor } \\
\text { materials (Quadrant IV) }\end{array}$ & $\begin{array}{l}\text { Poor spiritual, material } \\
\text { Kaya (Quadrant III) }\end{array}$ \\
\hline
\end{tabular}

Source: Irfan Syauqi Beik, Laily Dwi Arsyianti (2016: 93)

The table above can be explained as follows:

Website: http://jurnal.radenfatah..ac.id/index.php/ieconomics 
Quadrant I If the actual value of household spiritual score $(\mathrm{SH})$ is greater than the $\mathrm{SV}$ and the revenue was greater than MV.

quadrant II : If the value SH is larger than SV and lower revenue from MV

quadrant III If the value of SH is smaller than SV and revenues greater than MV.

quadrant IV If the value of SH is smaller than the SV and a smaller income from MV.

The last stage of the calculation of the indices CIBEST consisting of well-being index or $(\mathrm{W})$, the index of material poverty, spiritual poverty index, and the index of absolute poverty.

Welfare index (W):

$W=\frac{W}{N}$

Information:

W : Index welfare; $0 \leq \mathrm{W} \leq 1$

$\mathrm{W} \quad$ : The number of prosperous families (rich in material and spiritual)

$\mathrm{N} \quad$ : Total population (number of families to be observed)

1. The material poverty index $(\mathrm{Pm})$ :

$P m=\frac{M p}{N}$

Information:

Pm : Material poverty index; $0 \leq \mathrm{Pm} \leq 1$

$\mathrm{mp} \quad$ : The number of poor families rich material and spiritual

$\mathrm{N} \quad$ : Total population (number of families to be observed)

2. The spiritual poverty index (Ps):

$P s=\frac{S p}{N}$

Information:

ps $\quad$ : Index spiritual poverty; $0 \leq \mathrm{Sp} \leq 1$

Sp : The number of poor families spiritual and material enough

$\mathrm{N} \quad$ : Total population (number of families to be observed)

3. Absolute poverty index $(\mathrm{Pa})$

$P a=\frac{A p}{N}$

Information:

$\mathrm{Pa} \quad$ : Index welfare; $0 \leq \mathrm{Ap} \leq 1$

Ap : The number of poor families spiritual and material

$\mathrm{N}$ : Total population (number of families to be observed)

Website: http://jurnal.radenfatah..ac.id/index.php/ieconomics 


\section{DISCUSSION AND RESULT}

Rumah Belajar Ceria is a community on the initial establishment focused on improving the quality of early childhood education, was established in 2014 by using a small hut as the location of the first study. RBC started his narrative in the world of literacy by targeting children as a target of teaching and learning program, in early 2014 the enthusiasm of people very steeper but the facilities provided are minimal. After carrying out literacy programs during the three months ended in March 2014, this community was founded by chaired by Evan Saputra and eight others namely Amir alWahid, Erwin Tarzani, Ratna Mahardika, ISMI Yuliana, Tria Gustiningsih, Melta Triwesah and Damayanti Pratiwi well as the originator of the first RBC their community.

In August 2016, the learning process continues to be implemented and able to embrace -+60 children to learn together. In the middle of the process, based on the amount of waste disposed of used wood lots around the area studying the location of this community then decided to conduct trials oyster mushroom cultivation. After walking four months, the results of this cultivation be material to the public dissemination in Sungai Pedado to then engage them actively involved in the community development program as a manager.

January 2017, with financial assistance of Corporate Social Responsibility (CSR) of Pertamina RBC then set up the mushroom house with enough facilities to produce 5-10 kilograms of oyster mushroom per day. When found when the researchers conducted interviews, mushroom houses are scattered at some point in the village of Sungai Pedado with the beneficiaries as the main organizer program. The following data on the number of coaching programs mushroom growing on the river:

Table. 3

Characteristics Recipients Community Planting Program Mushrooms

\begin{tabular}{|l|l|l|l|}
\hline No. & Program Areas & Gender & number of People \\
\hline 1 & planting Mushroom & Man & 15 \\
\hline 2 & Fungus Treatment & Woman & 15 \\
\hline & Total & & $\mathbf{3 0}$ \\
\hline
\end{tabular}

Source: Primary data that have been processed

From table 3 it can be seen that as many as 30 community coaching program recipients mushrooms are divided into 15 people with the male sex act as a mushroom grower or served in the garden, then 15 female act as managers or in other words the addition value added(Processing and packaging). The system used in the development of this fungus is a program of buying and selling, between groups of people who act as mushroom growers in the garden to sell to community groups that act as a processor mushrooms at a price set together. The program is dominated by the fathers and mothers who are the people with the livelihoods of farmers and fishermen.

The Impact Program of Mushroom RBC for the Society are as following :

1. Impact of Mushroom By Material

In plain, where RBC with mushroom cultivation program have an impact on the creation of productive people who have a sideline activity in addition to their main job. One of the recipients named Ida said that the existence of mushroom cultivation

Website: http://jurnal.radenfatah..ac.id/index.php/ieconomics 
able to fill the empty time as mothers, it is said is very pleasant and easy to work together in a group that has been set. According to the size of the FPL have been made before it can be explained in the following table:

Table. 4

The average Community Expenditures Before and After Program

\begin{tabular}{|l|l|l|l|}
\hline No. & Before & After & Percentage \\
\hline 1. & USD 989 100 & Rp 1,475,233 & $49.14 \%$ \\
\hline
\end{tabular}

Source: Primary data that have been processed.

According to the table the average exposure of the public expenditure program recipients can be concluded that an increase of 49.14 per cent in the community in terms of household expenditure per month. It is caused by the passage of the process of production and sale of oyster mushroom products to consumers.

Furthermore, from the measurement of the poverty line of $\operatorname{Rp~1,246,926,~-~per~}$ household per month, then the average can be explained as follows:

Table. 5

Measurement With Poverty Line Petition

\begin{tabular}{|l|l|}
\hline Before & After \\
\hline USD 989 100<Rp 1,246,926 & Rp 1,475,233>1,246,926 USD \\
\hline
\end{tabular}

Source: Primary data that have been processed.

Based on the above table it can be concluded that an increase in the average expenditure on the beneficiaries of the program from the previous $\mathrm{RBC}$ is at the poverty line is above the poverty line after joining the mushroom farm program organized by $\mathrm{RBC}$. This suggests that the presence of RBC materially impact the increase in social welfare Sungai Pedado.

2. Impact of Mushroom Spiritually

Measurement spiritual figures of society using five measuring variables such as prayer, alms, fasting, worship, family and government policies that measured respondents who are the recipients of community programs $\mathrm{RBC}$ mushroom farm. The impact of the presence of RBC to the spiritual needs of rural communities Sungai Pedado can be explained in the following table:

Table. 6

Measurement With Spiritual Poverty Line

\begin{tabular}{|l|l|}
\hline Before & After \\
\hline $3.98>3$ & $4.24>3$ \\
\hline
\end{tabular}

Source: Primary data that have been processed.

Measurement spiritual figures of society using five measuring variables such as prayer, alms, fasting, worship, family and government policies that measured respondents who are the recipients of community programs $\mathrm{RBC}$

Website: http://jurnal.radenfatah..ac.id/index.php/ieconomics 
mushroom farm. According to the table above can be seen on average prior to the RBC community that spiritual figures Sungai Pedado community would be up enough spiritually category of 0.98 above the spiritual poverty line. Meanwhile, after the program RBC spiritual figures Sungai Pedado Village community increased by 0.26 to 4.24 on average. This is due to the increase in the intensity of worship performed by RBC volunteers in kerelawanannya activity.

Analysis on Receiving Communities Program CIBEST Mushrooms

a. Quadrant Cibest absence RBC Program

After the interviews and questionnaires regarding spiritual needs are represented by variables such as prayer, alms and infaq, fasting, worship, family and government policies with the object that deepened was the condition before receiving a program of $\mathrm{RBC}$, it can be analyzed by quadrant CIBEST like in pictures the following:

$(+)$

Spiritual Poverty line

$(-)$

\begin{tabular}{|l|l|l|}
\cline { 2 - 3 } & $\begin{array}{l}\text { Poor material 9 } \\
\text { Households (Quadrant II) }\end{array}$ & $\begin{array}{l}\text { Sejahtera 21 Household } \\
\text { (Quadrant I) }\end{array}$ \\
\cline { 2 - 3 } (-) $\quad$ Household absolute & Spiritual Poor 0 Household \\
\hline & Material Poverty Line & (Quadrant III) \\
\hline
\end{tabular}

Source: Primary data that have been processed

Based on the picture above, it can be seen that prior to their communities RBC materially the number of poor households amounted to 9 with prosperous figure amounted to 21 households, and for absolute poverty and spiritual can not be found in the village of Sungai Pedado. For comparison, the following will describe the current CIBEST quadrant has received RBC program.

\section{b. Quadrant Cibest with RBC Program}

After the interviews and questionnaires regarding spiritual needs are represented by variables such as prayer, alms and infaq, fasting, worship, family and government policies with the object that deepened is the current state has received a program of RBC, it can be analyzed by quadrant CIBEST as in the following picture:

Website: http://jurnal.radenfatah..ac.id/index.php/ieconomics 


\begin{tabular}{|c|c|c|c|}
\hline \multirow{3}{*}{ Spiri } & \multicolumn{3}{|c|}{$\begin{array}{c}\text { Figure. } 2 \\
\text { Quadrant CIBEST with RBC } \\
\text { MV }\end{array}$} \\
\hline & \multirow[t]{2}{*}{ ual Poverty line } & $\begin{array}{l}\text { Poor material } 2 \text { Household } \\
\text { (Quadrant II) }\end{array}$ & $\begin{array}{ll}\begin{array}{l}\text { Sejahtera } 28 \\
\text { (Quadrant I) }\end{array} & \text { Household } \\
\end{array}$ \\
\hline & & $\begin{array}{l}0 \text { Household absolute } \\
\text { poverty (Quadrant IV) }\end{array}$ & $\begin{array}{l}\text { Spiritual Poor } 0 \text { Household } \\
\text { (Quadrant III) }\end{array}$ \\
\hline
\end{tabular}

$(-)$
$(-)$
Material Poverty Line
$(+)$

Based on the picture above, it can be seen that prior to their communities RBC materially the number of poor households amounted to 2 with numbers totaling 28 households prosperous, and for absolute poverty and spiritual can not be found in the village of Sungai Pedado. From these results it can be seen that the addition of a prosperous household of 21 households to 28 households, while households are materially poor households was reduced from 9 to 2 households only. Progress contained in this research about society Sungai Pedado will be explained in the next point.

\section{c. Analysis of Poverty Index CIBEST}

Islami poverty indices contained in CIBEST models consist of well-being index, the index of material poverty, spiritual poverty index, and the index of absolute poverty. Based on the analysis CIBEST quadrant, have known the number of households that fall into each category. Through the results of the quadrant CIBEST then we will get the results of the calculation of the poverty index Islami. Here are the results of the calculation of the poverty index Islami.

Table. 6

Poverty Index CIBEST

\begin{tabular}{|l|l|l|l|}
\hline Cibest Index & without RBC & with RBC & Change (\%) \\
\hline W & 0.70 & 0.93 & 0.23 \\
Pm & 0.30 & 0.06 & $(0.24)$ \\
ps & 0,00 & 0,00 & 0,00 \\
Pa & 0,00 & 0,00 & 0,00 \\
SS & 3.98 & 4.24 & 0.26 \\
\hline
\end{tabular}

Source: Primary data that have been processed

Welfare index (W) represents the number of households that fall into the category of household welfare. To determine the impact of the distribution of zakat funds for the welfare of rural households Sungai Pedado research is done without and with the assistance of RBC program. Beradasarkan Table 4.5, the number of

Website: http://jurnal.radenfatah..ac.id/index.php/ieconomics 
households that are in the category of household prosperity has increased from 0.70 , or 70 percent, to 0.93 , or 93 percent. This means that an increase in household wealth index mustahik at 0.23 percent. These results show that the presence of RBC Community proven to improve household welfare index villagers Sungai Pedado.

Material poverty index $(\mathrm{Pm})$ describes the number of households that fall into the category of poor material, but spiritually rich. Analysis of material poverty index of households do without and in the presence of a community program of RBC. Beradasarkan of research that has been done, the result that without and with the charity which decreased by 0.24 percent. These results show that the presence of RBC proven programs can reduce household poverty index material Sungai Pedado rural communities.

Spiritual poverty index (Ps) describes the number of households fall into the category of poor spiritually but materially rich. Based on the data in Table 4.5, the index spiritual poverty of households without and with the RBC program unchanged.

Absolute poverty index $(\mathrm{Pa})$ represents the number of households fall into the category of poor materially and spiritually. Households in this category have been able to provide for the spiritual and material needs. Beradasarkan Table 4.5, the index of absolute poverty without and with the RBC program unchanged.

Besides the four index value noted above, there is the value of the SS or the average score of the spiritual condition of the whole family are observed. SS value in the table shows a value of 3.98 without the program with their 4:24 RBC and RBC program then increased by 0:26 percent. The SS value in general may indicate that family's spiritual state of the respondents already be above the poverty line and the spiritual without the program from RBC. Spiritual poverty line (SV) is the amount that is equal to 3 .

The results of the analysis of the poverty index of households mustahik islami is also similar to the results of research conducted previous research. These results indicate that with the help of charity will improve the welfare of the poor and the lower the index spiritual poor.

\section{CONCLUSIONS AND SUGGESTIONS}

Based on the results of research conducted then obtain the following conclusions:

1. Implementation of a mushroom farm program initiation and forms of community programs RBC, which has 30 members of the community with 15 men acting as farmers and 15 women as managers of post-harvest fungus. This program has been underway since 2016, with a system that is run by the farmer and manager of mushrooms imposed trading system whereby farmers sell to the manager. The program is already producing mushroom chips have been sold to a number of consumers.

2. Based CIBEST model shows that the presence of the fungus RBC livestock program can improve the welfare of society and lower the poverty index material. Household classification based model CIBEST categorized prosperous (quadrant I) as many as 28 households, poor material (quadrant II) by 2 households, spiritual poor does not exist, and that in the category of absolute poverty does not exist. 
I-Economic: A Research Journal on Islamic Economics

ISSN 2548-5601, e-ISSN 2548-561X

Vol 6. No 1. Juni 2020

\section{BIBLIOGRAPHY}

Adit Agus Prasetyo. "Analysis of the factors affecting the level of Poverty (case study 35 districts / municipalities in Central Java Year 2003-2007)". Thesis. (Faculty of Economics, University of Diponegoro, Semarang, 2010)

Amaroh S, "Filantropi Islam di Indonesia: Potensi dan Kendala", Addin Journal, vol. 2, issue 1, (2014)

Bank Indonesia, Indonesia Book Economic Report 2008 (Online), http://www.bi.go.id.

Beik, Irfan Syauqi, Laily Dwi Arsyianti, "Construction Of Cibest Model As Measurement Of Poverty And Welfare Indices From Islamic Perspective", Journal of Al-Iqtishad Vol 7, No. 01. UIN Syarif Hidayatullah Jakarta, 2015)

Beik, Irfan Syauqi, Laily Dwi Arsyianti, Islamic Development Economics, revised edition. (Rajawali Pers. Jakarta, 2016)

Charles S. Bamualim, Irfan Abubakar, The Revitalization of Islamic Philanthropy; Case Studies of Zakat and Waqf Institution in Indonesia, (Jakarta, The Ford Foundation and the Center for Language and Culture Syarif Hidayatullah State Islamic University. 2005)

Chusnan Jusuf "Modern Philanthropy Social go towards reconstructing" Journal of Research and Development of Social Welfare, Vol 12, No. 01, 2007: 74-80

Didien Hafidhuddin, et al. The Power of Zakat Zakat Management Comparative Studies of Southeast Asia. (Malang State Islamic University in cooperation with the Research Center of Zakat and Waqf "El-Zawa" 2008).

Edi Suharto, Issues Thematic Social Development; Conception and Strategy, (Jakarta, Balatbangsos Ministry of Social Affairs. 2004)

Em Zul Fajri and Queen Aprilia Twilight, Complete Dictionary of Indonesian, undated, Difa Publisher,

Erna Witoelar, The Millennial Generation Change Map Philanthropy Indonesia, https://filantropi.or.id, Accessed March 17, 2019, at 06:27.

Imron Hadi Tamin, "Peran Pilanthropy In Poverty In The Community Lokal", Journal of Sociology of Islam, Vol. 1, 1. (Udayana University, 2011)

John Mardimin, Critique Dimension Development Process in Indonesia. (Jogjakarta: Canisius, 1996),

Karim, Adiwarman 2007, Microeconomics Islami, third edition, RajaGrafindo.

LP3EI, Islamic Economics, King Grafindo 2007 Observing Debt Position of Indonesia, the Economic Daily Balance of 13 April 2009.

Mubyarto and Sueratno, Economic Research Methods, Cet. I (Yogyakarta: FE UGM, 1996), p 25

Nety Widyaningsih. "Impact Study Zakat in South Sulawesi with Model CIBEST”. Al-Iqtishodia. JURNAL EKONOMI ISLAM REPUBLIKA , KAMIS,28 JANUARI 2016

Nur Indriantono and Bambang Supomo, Business Research Methodology: To Accounting and Management, Cet. 1 (Yogyakarta: BPFE, 2002), p 3.

Primary C.." Productive utilization of Zakat in Reducing Poverty beradasarkan CIBEST Model: A Case Study of PT for Community LAZ PM Al Bunyan", Thesis. Bogor (ID): Institut Pertanian Bogor. (2015)

Website: http://jurnal.radenfatah..ac.id/index.php/ieconomics 
Siddiqi, Nejatullah, 1989, Islamic economic thinking during the writing of a review. Translators: Nurin enterprise. Dewan Bahasa Dan Pustaka Ministry of Education Malaysia

Sugiyono. Business Research Methods. (Alfabeta, Bandung. 2001), p.61

Supardi, Economics and Business Research Methodology, Cet. I (Yogyakarta, UII Press, 2005).

The Central Bureau Statitistik, 2017, Statistics Indonesia, (Online), http://www.bps.go.id.

Thomas Silk, 1999, Philanthropy and the Law in Asia; Challenges for Indonesia, Jakarta, PT Fristi Pratama

Timotheus Lesmana Widjaja, Seminar Philanthropy Goes To Campus Learning Forum, October 17th, 2018, University of Indonesia

Tofallis, Chris \& Sargeant, Adrian, 2000, the Charities Assessing the Using Data Envelopment Analysis. Center for Business Performance, Cranfield University. 